
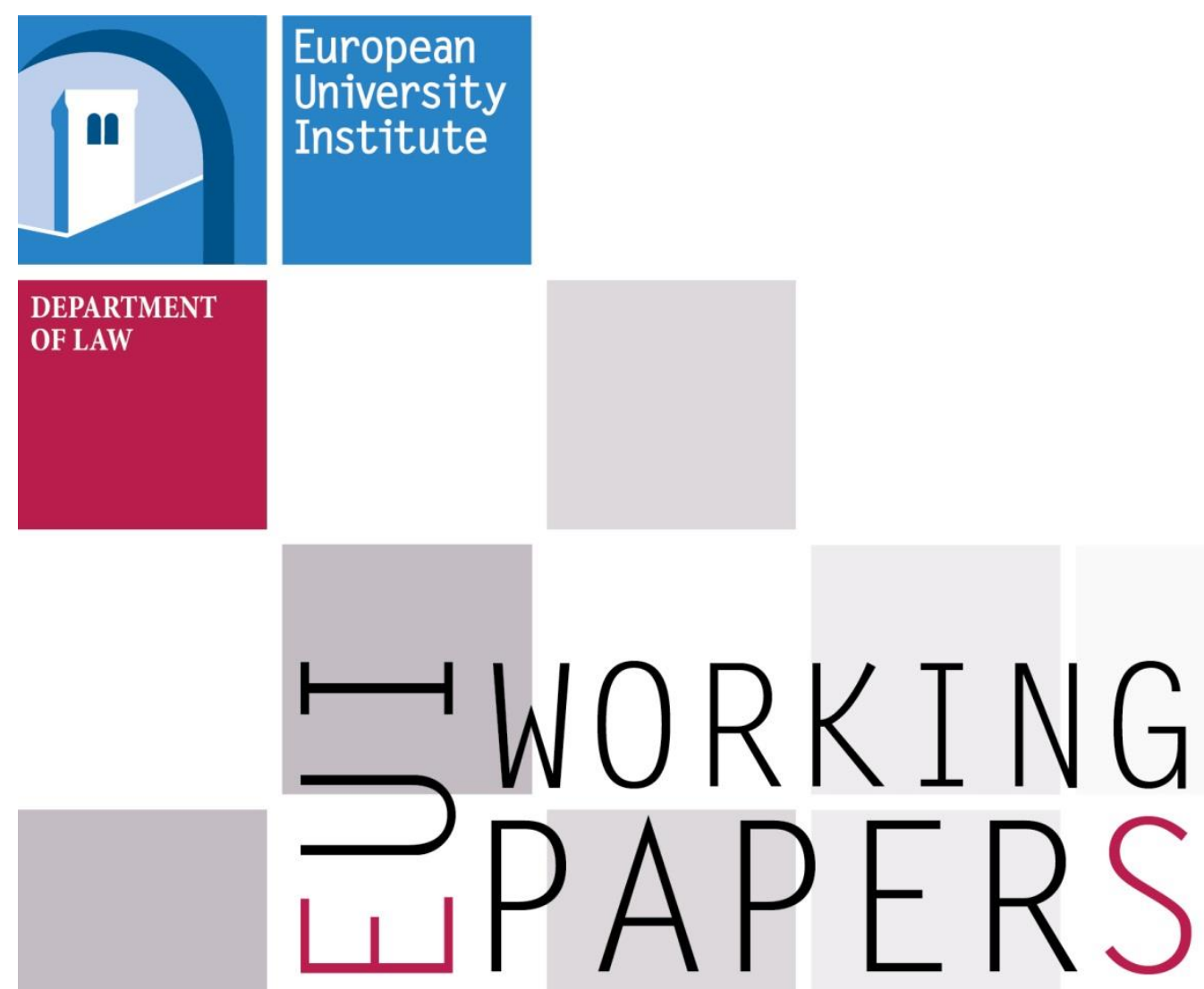

LAW 2018/15

Department of Law

Union citizenship and beyond

Hans Ulrich Jessurun d'Oliveira 

European University Institute Department of Law

\section{UNION CITIZENSHIP AND BEYOND}

Hans Ulrich Jessurun d'Oliveira

EUI Working Paper LAW 2018/15 
This text may be downloaded for personal research purposes only. Any additional reproduction for other purposes, whether in hard copy or electronically, requires the consent of the author. If cited or quoted, reference should be made to the full name of the author, the title, the working paper or other series, the year, and the publisher.

ISSN 1725-6739

(C) Hans Ulrich Jessurun d'Oliveira, 2018

Printed in Italy

European University Institute

Badia Fiesolana

I-50014 San Domenico di Fiesole (FI)

Italy

www.eui.eu

cadmus.eui.eu 


\begin{abstract}
In this essay the development, since 1992, of the concept of European citizenship is traced, alongside the changing attitude of the author towards this novel status. The blurred edges of the concept are explored. Connecting factor to European citizenship is the possession of the nationality of a member state. Is nationality identical with 'peoples' in the Treaties? And: are member states the masters of definition of who are their nationals? And is the status of European citizen really dependent on the nationality of member states, or is it gradually the other way round, given the view of the ECJ that the first is 'intended to be the fundamental status'? Although there is no transfer of competence of nationality law, nevertheless domestic laws should have 'due regard to European law.' In Rottmann a decision by national authorities was subjected to the European principle of proportionality, in Tjebbes a whole legal provision in the national law of the Netherlands was, according to the AG, not in line with Union law. This is a constitutional battle, as the definition of its nationals is a constituent part of being a (member) state. Brexit sheds a new light on the importance of Union citizenship, primarily as its entrance to the freedom of movement. Finally, a number of loose ends are identified and questions formulated.
\end{abstract}

\title{
Keywords
}

European citizenship; member state nationality; peoples; fundamental status 
Author contact details:

Prof. dr. Hans Ulrich Jessurun d'Oliveira

Professor emeritus University of Amsterdam

European University Institute

Email: hudo@xs4all.nl 


\section{Table of contents}

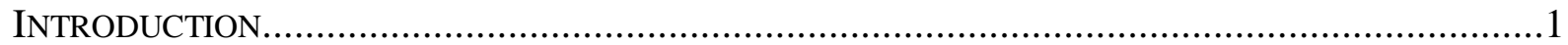

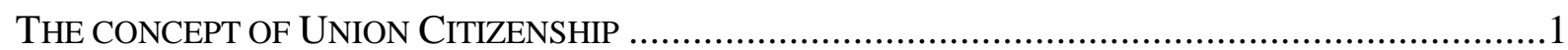

THE CONNECTING FACTOR: NATIONALITY OF A MEMBER STATE............................................4

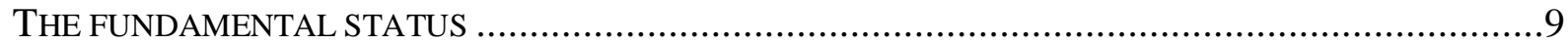





\section{Introduction}

When you ask your neighbour whether she is a Union citizen you may expect a negative or a question mark. The status has not really sunk in, notwithstanding the freedom of movement that goes with it or the right to elect members of the European Parliament. Recently people became aware of the status because of Brexit, as they were suddenly confronted with what they thought was an inherent right turning out to be a fragile status to be taken away through Brexit. ${ }^{1}$ Time to reflect once more on Union citizenship. This contribution addresses a few core issues concerning the status: the concept itself (par.2), nationality of a member state as the connecting factor between a person and Union citizenship (par.3), and the prospects of the 'fundamental status' (par.4). These themes will be looked at with a double-faced head: history and future of the concept are brought into play.

\section{The concept of Union Citizenship}

Union citizenship was formally instituted by the Maastricht Treaty in 1992. Spanish Prime Minister Gonzalez took the initiative but it was prepared long before and, as an idea, had many fathers and mothers. Immanuel Kant for instance, in his Zum ewigen Frieden, stated that '...ursprünglich aber niemand an einem Orte der Erde zu sein mehr Recht hat, als der andere.' And in his utopian view he dreamt of a ius cosmopoliticum 'so fern Menschen und Staaten, in äussern auf einander einfliessenden Verhältnis stehend, als Bürger einer allgemeinen Menschenstaats anzusehen sind.' It is interesting to notice that Kant considered the right to hospitality and the freedom of movement of people as the central implication of the proposition that nobody has a stronger right to be somewhere than anyone else. On a smaller scale, it was the right to freedom of movement that was the core of the rights entailed by being a European citizen. This despite the fact that many definitions of citizenship both by political scientists and lawyers start out with political rights as the nucleus of the concept.

Mention may be made here as well of Altiero Spinelli (1907-1986), who is considered to be nothing less than one of the founding fathers of the two post-war Europe organisations: the Council of Europe and the European Communities. During his imprisonment as a communist opponent of the fascist Mussolini regime, he served long prison sentences and was exiled to a small island off the Italian coast between Rome and Naples: Ventotene. ${ }^{2}$ Here he studied the American Federalists and issued in 1941, with some others, the Ventotene Manifesto, in which he drew up a blueprint for a federalist Europe, beyond the nation- states, as the only way he saw to combat fascism and national socialism. He had learned from James Madison that the prospects for freedom were greater in a larger federation than in a small one. ${ }^{3}$ He pleaded for a continental citizenship alongside with citizenship of the national states. Much later, as an MEP, he inspired the Spinelli plan for a federal Europe, adopted with a large majority by the European Parliament, which paved the way for the Single European Act and the Maastricht Treaty. ${ }^{4}$

There are many other inspirations. Let us return to the 16th of June 1940. France is invaded by the German army and stands on the brink of collapse. Talks between the French and British governments are conducted with a view to prevent — or at least postpone - the imminent surrender of the French

\footnotetext{
${ }^{1}$ See H.U.Jessurun d'Oliveira, Brexit, Nationality and Union Citizenship: Bottom Up and Top Down, in: Europa als Rechtsund Lebensraum, Liber Amicorum für Christian Kohler (2018), pp 201-214.

${ }^{2}$ Ventotene was already used as a place of exile in ancient Rome: Emperor Augustus isolated his daughter Julia there because of what he saw as her excessive adultery. Recently, 22 august 2016, prime minister Renzi of Italy chose this lieu de mémoire for a mini-summit on the future of Europe after Brexit.

${ }^{3}$ For a recent comparative study, see Jeremy B. Bierbach, Frontiers of Equality in the Development of EU and US Citizenship(2017).

${ }^{4}$ The federalists assembled as The Crocodile Club, named after a Strasbourg restaurant, and since 2010 there has been a 100MEP Spinelli group, led by Verhofstadt, Cohn-Bendit and others.
} 
army and to allow first and foremost the French fleet to seek refuge in foreign ports. Protagonists: General de Gaulle and Winston Churchill with his war cabinet. While De Gaulle is eagerly waiting in the next room, the war cabinet is drafting a concept Declaration of Union to be offered as support to prime minister Raynaud of France. It states e.g.:

The two Governments declare that France and Great Britain shall be no longer two nations, but one Franco-British Union.

The Constitution of the Union will provide for joint organs of defence, foreign, financial, and economic policies.

Every citizen of France will enjoy immediately citizenship of Great Britain; every British subject will become a citizen of France. ${ }^{5}$

In view of later developments it is remarkable to see General de Gaulle urging a union between France and Great Britain and accepting a common citizenship, and to witness the willingness of the British Government to bridge the Channel in terms of statehood and citizenship: these were the days of 'Brintroitus'. See, by contrast, the historian Boris Johnson, foreign minister of the Brexit-cabinet, now comparing the European Union with Hitler and Napoleon.

At the outset I took a dim view of European Citizenship. I wrote in 1995: 'The populations of the Member States have not asked for citizenship; it has graciously been bestowed upon them as a cover-up for the still existing democratic deficit. As an alibi it may please Brussels; whether it changes anything in the sceptical attitude and weak position of the populations of the Member States is, in my view, rather improbable. ${ }^{6}$ The term amounted to not much more than a gaudy ribbon around a motley ensemble of already existing rights, first and foremost the freedom of movement for a small number of economically active nationals of member states. What difference can a word make? Well, my initial analysis proved to be wrong. I had to admit gradually that a word can makea difference. The word citizenship raises expectations about developments connected with ideas about citizenship. It is a fertilizer with its own growth potential. These ideas are, as is to be expected, manifold, blurred, and range from a status in civil society to a concept of persons as political agents.

Indeed, one of the disturbing problems with the definition of citizenship is the recurring use of citizenship as synonymous with nationality. ${ }^{7}$ In a recent study, Olivier Vonk, who works at the EUDO Citizenship Observatory, based at the EUI, states:

Since the Observatory uses the term citizenship in describing the domestic nationality law rules in forty-seven European Countries, this practice provides further justification for giving citizenship a more prominent place than I did in previous publications. ${ }^{8}$

If this is the prevalent view at the EUDO Citizenship Observatory, then it is difficult to distinguish between Union citizenship and its connecting factor, the possession of the nationality of a Member State. In order to be a Union citizen, one has to be a 'citizen' of a member state. Are there two citizenships involved, two nationalities, or one citizenship and one nationality? This is not only wordplay. Denmark,

\footnotetext{
${ }^{5}$ Winston Churchill, The Second World War, Vol. II, Their Finest Hour, p. 182 ff. Nothing came of the declaration: Prime Minister Raynaud could not collect the assent of his cabinet and had to resign; Pétain then took over and eventually bred the Vichy regime. De Gaulle escaped by the skin of his teeth: he jumped on board a small airplane that brought the British ambassador back from Bordeaux to London, pretending to see the diplomat off.

${ }^{6}$ H.U. Jessurun d'Oliveira, Union Citizenship: Pie in the Sky? In: Allan Rosas \& Esko Antola, (eds), A Citizen's Europe. In Search for a New Order, 1995, pp 58-84 (at 84)

${ }^{7}$ In the Commentary to the European Convention on Nationality ad art.2 one reads: 'with regard to the effects of the Convention, the terms 'nationality' and 'citizenship' are synonymous'

${ }^{8}$ Olivier Vonk, Reflections on Comparative Law and Legal Translation in Studying Different Citizenship Regimes. Nederlandse Vereniging voor Rechtsvergelijking, nr. 73 (2016), p.56.
} 
already extremely aloof about the Maastricht Treaty, which it had rejected by referendum in June 1992, issued a unilateral declaration half a year later, stating emphatically that

1. Citizenship of the Union is a political and legal concept which is entirely different from the concept of citizenship within the meaning of the Constitution of the Kingdom of Denmark and of the Danish legal system. Nothing in the Treaty on European Union implies or foresees an undertaking to create a citizenship of the Union in the sense of citizenship of a nation-state. (...) 2. Citizenship of the Union in no way in itself gives a national of another Member State the right to obtain Danish citizenship or any of the rights, duties, privileges or advantages that are inherent in Danish citizenship by virtue of Denmark's constitutional, legal and administrative rules. $(\ldots)^{9}$

Although in the English version the terms nationality and citizenship are being used, the Danish word 'borgerskap' refers to both concepts and may have caused the Danes to declare that the Unionsborger is not at all identical to the statsborger. There is more.

We should not forget that at the stage of the negotiations towards the European Constitution in 2002, Giscard d'Estaing issued a paper in which he suggested that "member states nationals would have "double" nationality in the future.' And the Preliminary Draft stated: This article establishes and defines Union citizenship: every citizen of a Member State is a citizen of the Union; enjoys dual citizenship, national and European citizenship; and is free to use either as he or she chooses, with the rights and duties attached to each .(... ${ }^{10}$ Small wonder that the concept of Union citizenship is surrounded by complexities and perplexities.

The Treaty, however, differentiates, rightly so, between nationality and citizenship. It indicates that holding the nationality of a member state entails being a citizen of the Union, and that this citizenship 'shall be additional to and not replace national citizenship.' Nationality then is seen as a formal legal bond between a person and a state, whereas citizenship refers to substantive rights and duties attached to nationality, according to a municipal legal system, and to Union citizenship, according to the Treaty and secondary legislation.

It is remarkable that one can be called a citizen of an international organisation. We do not normally see ourselves as citizens of the United Nations, or of the Bureau international des poids et mesures, or of the Council of Europe. There are no citizens of NAFTA. The term reveals something about the various aspirations of the EU; how it strives to become an entity akin to a state, a federal thrust. It bestows on all persons holding the nationality of a member State the status of citizen in this special Europe-wide organisation with its institutions. The term promises to these persons political influence, legitimising the European Parliament and in bridging at least partially the so-called democratic deficit. It suggests forms of protection as well.

The attributes of Union citizenship are only partially defined. It is telling that the catalogue of the rights attached to Union citizenship in the TFEU is no more than a rough indication: Art. 20 TFEU lightheartedly appends 'inter alia' to its list, a clear indication that it is open-ended. It may grow and new rights and duties may be added. We have to look, according to Art. 20, 'in the Treaties'. Hence the discussion about the extent of the rights and duties that can be brought under the heading of Union citizenship has animated the debate, not only among scholars, but also in the courts. Are fundamental rights, as mentioned in the Charter and the ECHR, part and parcel of Union citizenship? No, some would say, these rights can be invoked by everyone, they are not specific. Yes, others assert, the exclusivity of the right is not the criterion, as demonstrated by the right to petition the EP (Art. 227 TFEU ) which is assigned to 'any natural or legal person residing in a Member State', and the same goes for the right to

\footnotetext{
${ }^{9}$ Preliminary Draft, Title II, Art.5.

${ }^{10}$ Preliminary Draft, Title II, Art.5.
} 
apply to the European Ombudsman (Art.228 TFEU). ${ }^{11}$ The central right to move and work freely in the Member States is granted to all nationals of non-EU EFTA member states as well.

In other words, the edges are blurred, and I have come to see this as an asset of the concept. It has grown to be a not-fully-exclusive status of nationals of member states. It changed from a symbolic ribbon around a set of rights as I saw it at the time, into a meaningful dynamic concept of the relationship between the EU and the bulk of the population. The impact of the political rights attached to it, especially the right to vote and stand for elections in the EP, has increased through the increased powers of the EP. Secondary legislation and case-law show a definite shift from market citizenship of the economically active to a rounder, fully-fledged form of citizenship. Up till now, as we all are aware of the waning enthusiasm for the European project. Many Union citizens are not aware of the fact that they are just that, and the meagre turnovers at the election of MEPs not only reproduce the aversion of the voters to politics in general, but also show their distrust of what is perceived as the black box of 'Brussels'. So my current position has, possibly against the tide, changed from scepticism into two hurrahs for Union citizenship. Brexit may kindle a new enthusiasm for the status.

\section{The connecting factor: nationality of a member state.}

'Every person holding the nationality of a member state' (Art.20 TFEU). Nationality, then, is the unique pass to Union citizenship. I have had, from the outset, two bones of contention with this connecting factor. First, its exclusiveness, and second, the way the European Court of Justice has dealt with the nationality issue.

a)

The framers of the Treaty of Lisbon, bothin its preamble and its Art.1, talk about bringing about 'an ever closer union among the peoples of Europe', and 'desiring to deepen the solidarity between their peoples.' Is the term 'people' identical with 'nationals of a specific member state'? The ECJ held that this is not the case. In Spain v. UK it stated that 'the term 'peoples', which is not defined, may have different meanings in the States and languages of the Union." 12 These cases concerned the right to vote for the EP. Of course, this franchise may be narrowed down by European legislation to nationals of member states, but as long as this is not the case, the situation exists that there are, here again, non-nationals entitled to rights which belong to Union citizens as enumerated in Art. 20 TFEU as well. No exclusivity in this central political right. 'Peoples' may have more surprises in store in other areas than that of voting rights.

It is interesting to notice that the Court leaves it to the member states to define their 'peoples'. The member states are free to include non-nationals in their respective 'peoples', such as third country permanent residents, refugees, stateless persons etc. These, too, are then subject to the desire to deepen the solidarity and to create an ever-closer union. Why would it be unacceptable to grant them the status of Union citizens? Many categories among them already have a certain privileged status under EU law. Over the years various authors and institutions have militated for inclusion of third-country permanent

\footnotetext{
${ }^{11}$ There are more examples of non-exclusivity: Gibraltarians have the right to vote for the European Parliament, though not as nationals of a member state but 'qualified Commonwealth citizens', cf ECJ C 145/04 Spain v. United Kingdom, 12 September 2006. See also Declaration Nr. 55 by Spain and the UK, annexed to the Lisbon Treaties: 'The Treaties apply to Gibraltar as a European territory for whose external relations a Member State is responsible. (...)' And the right to move and reside freely within the territory of the member states is granted, derivatively, to third country and stateless relatives of Union citizens; on the other hand this right has been withheld from nationals of new member states for transitional periods.

12 Spain v. United Kingdom C-145/04, at 71. Idem in the decision of the same day, Eman and Sevinger, C-300/04, 12 September 2006, at 44. Eman and Sevinger became later Prime Minister and Minister in the Government of Aruba, a 'land' in the Kingdom of the Netherlands.
} 
residents in the territories of the member states. ${ }^{13}$ For them, 'peoples' are populations of the member states that should be included in the EU as citizens. Union citizens are not only nationals, but persons who are legally domiciled in the territories of the member states as well. The non-discrimination principle of Art. 18 TFEU 'on grounds of nationality' should be extended to the prohibition on grounds of domicile. In innumerable respects, non-nationals residing in the EU are subject to the legal order of the EU; they should have a voice as Union citizens as well. One is aware of the fact that this is a constitutional issue: the member states would lose part of their grip on non-nationals on their territory if the latter derived rights under EU law for being Union citizens. The self-definition of states as nationstates would be diluted and the balance between EU and the Member States would shift. Indeed, it has shifted already as the ECJ has strengthened the grip of Union law on sedentary citizens by demolishing bit by bit the concept of the 'internal case'. Furthermore, many third country nationals and stateless persons have rights, derived from Union citizens, as family members. Still, it is not acceptable to divide the populations of the member states into Union citizens and others, into first-class citizens and secondclass citizens. This brings me to the second issue.

b)

Who defines who is a national of a member state? The answer seems so simple. The European Convention on Nationality states at the outset (Art. 3) as a general principle: 'Each State shall determine under its own law who are its nationals.' Full stop. This is considered to be the codification of the guiding principle of international law. The determination by a state is not unfettered though: human and fundamental rights delineate the boundaries of the discretion.

If the competence of the state in defining who is its national and who is not is beyond doubt, this does not mean that all other states have to recognize the outcome of this legislative competence. Under international law, as again codified in the European Convention on Nationality (Art. 3 s.2) other states shall recognize this law 'in so far as it is consistent with applicable international conventions, customary international law and the principles generally recognized with regard to nationality.' The question thus arises of whether the Union Treaties allow the member states and the European Union to withhold recognition to elements of member states' municipal nationality laws. The Convention is silent about acceptance by international organizations. This is remarkable as the Convention dates from 1997 and was framed in the Council of Europe, which was well aware of the existence of the European Union. But even if one accepts that international organisations, with their own specific legal orders, are allowed to act in the same way as states, the question remains whether they have the right not to accept effects of the nationality (laws) of a member state? Are there grounds in the treaties or elsewhere for refusing to accept the outcome of the laws of the member states, or, for that matter, third states?

The member states have repeatedly stated that this is not the case, and that the competence to define their nationals is their 'reserved domain.' Thus, annexed to the Maastricht Treaty is a Declaration by the Conference, indicating that

13 Among many others, P. van Dijk, Free Movement of Persons: Towards European Citizenship, SEW 1992, 277-307, Alvaro Castro Oliveira, Third Country Nationals and European Union Law, doctoral thesis EUI, (1996); Bernitz and Lokrand Bernitz, Human Rights and European Identity: the Debate about European Citizenship, in: Philip Alston c.s.(eds),The EU and Human Rights (1999), p.522: 'The conclusion is that legal abode in the Union is a more appropriate criterion than nationality in respect of free movement and other Community Rights'; O'Keeffe, 'Union Citizenship', in: O'Keeffe and P. Twomey (eds), Legal Issues of the Maastricht Treaty (1994),p.104 et seq.; Siofra O’Leary, European Citizenship, The Option for Reform (Institute for Public Policy Research, 1996); D. Kochenov, The Essence of EU Citizenship Emerging from the Last Ten Years of Academic Debate: Beyond the Cherry Blossoms and the Moon?, ICLQ,vol.62,januari 2013,p.97 et seq., and the authors mentioned there in footnote 47; Ernst Hirsch Ballin, Citizens Rights and the Right to Be a Citizen (2015) p.108; H.U.Jessurun d'Oliveira, Union Citizenship: Pie in the Sky? ( 1.c. nt.7), at 80; idem, Europees burgerschap: dubbele nationaliteit? In: Europees burgerschap (Asser instituut Colloquium Europees recht, 33rd session) 2003, p.91-125 (at 99). See ECOSOC 'Opinion on a More Inclusive Citizenship to Immigrants' Soc/479 1 October 2013: 'The Committee proposes that, in future, when the EU undertakes a new report of the Treaty (TFEU), it amends art.20 so that third-country nationals who have stable, long term resident status can also become EU citizens.'(para.1.11). 
'wherever in the Treaty establishing the European Community reference is made to nationals of the Member States the question whether an individual possesses the nationality of a Member State shall be settled solely by reference to the national law of the Member State concerned. Member States may declare, for information, who are to be considered their nationals for Community purposes by way of a declaration lodged with the presidency and may amend any such declaration when necessary.'

At the Edinburgh summit of December 1992, even after Micheletti, they repeated, according to the Conclusions of the Presidency, 'The question whether an individual possesses the nationality of a Member State will be settled solely by reference to the national laws of the Member State concerned.' ${ }^{14}$

This is no small matter. In the end it concerns the existence of the member states insofar as a state is defined not only by territory and governmental organisation, but also by its nationals, citizens. If a state is not free to define who are its nationals, this loss of competence is at the same time not only a reduction of sovereignty, but even a loss of statehood. This fact, 'the most sacred of cows' ${ }^{15}$, has coloured my position on this issue.

We all are aware of the developments. In 1992, the ECJ in its judgment Micheletti ${ }^{16}$ initiated a series of decisions in which it held that ' $[u]$ nder international law, it is for each Member State, having due regard to Community law, to lay down the conditions for acquisition and loss of nationality.' Note that this is a misguided obiter dictum in two ways: in the first place because Micheletti was about the effects of Micheletti's undisputed Italian nationality in Spain under Community law, and in the second place because it intimated that international law entailed or obliged Member States to frame their nationality laws with due regard to Community law. That was in my mind begging the question, and I do not see any corroboration for the Courts assumption. According to international law the matter is still the 'reserved domain' of the state concerned. The phrase was nevertheless repeated in Kaur ${ }^{17}$, Zhu and Chen $^{18}$, and in Rottmann ${ }^{19}$, without any explanation why the Court deviated from Art. 3 of the European Convention on Nationality or the previous Hague Convention of 1930 Concerning Questions relating to the Conflict of Nationality Laws (Art.1). I submit that international law is silent about the role of Union law in controlling the competence of member states in matters of nationality.

The whole issue is one of recognition, of acceptance, by the Union and its member states, not one concerning the determination of acquisition and loss of nationality. In other words: the sedes materiae is Art. 3 s.2, not Art. 3. s. 1 of the ECN. No freedom of movement allowed here. This is a difference with a term as 'worker' under Union law: there no international Conventions stand in the way of defining the term, for good reasons, uniformly under Union law, and to take away definition power from the member states. $^{20}$

Importantly ,'nationality' under Union law may differ from nationality in the laws of the member states. Various member states have indicated in unilateral declarations who are to be considered their nationals for Union law purposes, Germany and Great Britain in particular. Although these declarations included and excluded many millions of persons holding the nationality of these states, no protests from the other

\footnotetext{
${ }^{14}$ European Council in Edinburgh, 11-12 December 1992, Conclusions of the Presidency, Part B. Annex 1, 53.

15 Sergio Carrera Nuñez, How much does EU Citizenship Cost? The Maltese Citizenship-for-Sale Affair: A Breakthrough for Sincere Cooperation in Citizenship of the Union?, in: Sergio Carrera Nuñez and Gerard René de Groot, eds, European Citizenship at the Crossroads. The Role of the European Union on Loss and Acquisition of Nationality (2015), p.293-326 (at p.293).

${ }^{16}$ Micheletti and others, 7 July 1992, C-369/90.

17 Kaur, 20 February 2001, C-129/99

${ }^{18}$ Zhu and Chen, 19 October 2004, C-200/02

${ }^{19}$ Rottmann, 2 March 2010, C-135/08.See my case-note in 7 European Constitutional Law Review (2011) 138: Decoupling Nationality and Union Citizenship, and generally the literature listed in : Gerard-René de Groot \& Olivier Willem Vonk, International Standards on Nationality Law ( 2015), p 574-576.

${ }^{20}$ Cf ECJ 23 March 1982, Levin, C- 53/81.
} 
member states of the Union were to be heard, and the $\mathrm{ECJ}^{21}$ accepted them without any restraint. This means that nationality in the Treaties is a form of functional nationality: not for all purposes, but for the specific function of being a connecting factor to the Union legal order, especially its chapters on Union citizenship and the prohibition of discrimination. Therefore it is allowed, on the one hand, for member states to indicate which of their nationals are to be considered 'nationals' for Union purposes, and on the other hand, for the Union and its member states to consider whether these indications hold water. Or, for that matter, if they have to be curtailed or extended.

But Union law is from my point of view not yet allowed to interfere with the competence of the member states to determine who are or who are not their nationals. There is no competence in the treaties to deal directly with the laws on nationality of the member states. The idea that the obligation for sincere cooperation (Art. 4 s.3 TEU) can be used as an argument that the member states should allow inroads into their laws on nationality is not convincing. Art. 4 s. 1 and 2 and Art. 5 TEU are more appropriate as arguments for the proposition that, as long as an explicit transfer of powers by the Treaties in the area of the law on nationality has not taken place, then according to international law the competence of each state to determine under its own law who its nationals are is unscathed. Competences not conferred by the treaties shall remain with the member states (Art. 5.s.2 TEU). Especially, it might be added, when it concerns such a sensitive and central issue as nationality. Laws on nationality belong to the identity of the member states and their fundamental constitutional structures to be respected by the EU, according to Art. 4 s.2 TEU. Although these have to be interpreted restrictively, they are still in place. ${ }^{22}$

This has been my position since Micheletti, and I remain there. But this does not mean that I disagree with the outcome of Rottmann. Rottmann and its predecessors are wrongly decided in obliging the member states (under international law) to have due regard to Union law in matters pertaining to the loss and acquisition of their nationality. But I do subscribe to the idea that the Union and its member states have a competence to accept or refuse the outcome of these laws for Union purposes. Union law is indeed involved when it comes to the recognition of the acquisition or the loss of nationality of member states, because Union citizenship is necessarily at stake. Therefore general principles of Union law, including the Charter and the ECHR, both procedural and substantive, are to be taken as guidelines in looking at the laws of the member states and their application.

Let us give an example of this scrutiny. According to the Dutch law on nationality, a person holding both Dutch nationality and a second nationality automatically loses his or her Dutch nationality after having resided for more than ten years abroad without receiving, on his /her request, a new passport or confirmation of Dutch nationality. 'Abroad', i.e. not having residence in the Netherlands or in the territories of the European Union. ${ }^{23}$ In my view, the Union is not allowed to interfere with this provision, but it is free not to accept the outcome for Union purposes, and still consider a person, though in this way divested of his or her Dutch nationality under Dutch law, as a Union citizen under Union law. The Union may hold the provision to be contrary to Art. 4 sub c and Art. 7 s. 1 of the European Convention on Nationality, and to Art. 47 of the Charter and Art. 6 of the ECHR.$^{24}$ The provision is arbitrary, exceeds the limits drawn by the ECN which do not target the first generation of Dutchmen abroad, but subsequent ones, and is under-inclusive in its bureaucratic criteria for maintaining a genuine link. It is furthermore

\footnotetext{
${ }^{21}$ See Kaur, above, note 18.

${ }^{22}$ See, in the field of defining the concept of spouse in Directive 2004/38 as including same-sex marriages: ECJ (Grand Chamber) 5 June 2018, Case C-673/16 (Coman, Hamilton and Asociatia Accept v. Inspectoratul General pentry Imigrari, Ministerul Afacerilor Interne ) with my comments in Nederlands Juristenblad 2018, p. 2060-2064.

${ }^{23}$ Art. $15 \mathrm{~s} .1 \mathrm{sub}$ c of the Dutch Code on Nationality.

${ }^{24}$ See H.U. Jessurun d'Oliveira, Automatisch verlies nationaliteit voor Nederlander buitenaf onhoudbaar. Nederlands Juristenblad 2016, p.248-255 ; and see, in the same vein, the Report by the Dutch National Ombudsman, Rapport verlies nationaliteit .'En toen was ik mijn Nederlanderschap kwijt...'Report 10 May 2016, nr.2016/145.
} 
not geared to the specificities of the individual case. The ECJ is asked to decide on this provision, which will probably not bear the test developed in Rottmann. ${ }^{25}$

It is the Dutch Council of State that requested a preliminary ruling in its decision of 19 April 2017.The case is still pending. A.G.Mengozzi, however, in his conclusions (12 July 2018) considered that the provision was not contrary to Art. 20 TFEU and article 7 of the Charter. In one case a minor was involved, and here the AG was clear and adamant:

L'article 20 TFUE et l'article 7 de la Charte des droits fondamentaux de 1 'Union européenne doivent être interprétés en ce sens qu íls s'opposent à une disposition législative telle que l'article 16, paragraphe 1 ,sous d) et 2 de la loi sur la nationalité néerlandaise en vertu de laquelle une personne mineure, ayant également la nationalité d'un pays tiers, perd de plein droit, sauf cas exceptionnel, la nationalité de son Etat membre,et, partant, le statut de citoyen de l'Union, en conséquence de la perte de la nationalité par son parent.

According to the AG, a minor is not a second class Union citizen, and should have the same right to block the loss of his nationality as his parents. The interests of the child do not coincide with the unity of nationality in the family as the Dutch Government proposed to explain the automatic loss of nationality by the children of a parent who loses his nationality. If the Court follows, that would be the first time that a legislative provision would be struck: in Rottmann only an individual decision by the administration was targeted.

An opposite example is the Maltese case. European institutions took courage from the Rottmann judgment in attacking the Maltese Individual Investors Programme allowing rich persons to 'buy' Maltese nationality and by that token Union citizenship. Both the Commission and the European Parliament exerted pressure, successfully, on Malta to include as a 'genuine link' a condition of effective residence on the foreign investors. ${ }^{26}$ In the scheme just proposed these interventions are not acceptable, but the Union, and the member states, are possibly in a position to refuse these new Maltese citizens their entailing status of citizens of the Union. This depends, of course, on arguments derived from principles of Union law. I agree with Sergio Carrera that these institutions started on a dangerous path in insisting on the need for a genuine link, invoking bad old Nottebohm. In the first place one should bear in mind that in Micheletti, the simple fact that Italy acknowledged Micheletti as its citizen, although he had lived all his life in Argentina and had only the scantiest of links, iure sanguinis, with Italy, allowed him to claim his European citizenship. The Court explicitly denied Spain the right to add any further conditions.

In the second place: Nottebohm is precisely an example where it was not the (Liechtenstein) nationality of a person that was denied (by Guatemala), but only one of the consequences, the exercise of diplomatic protection against another state.

In the third place, to introduce one or another type of 'genuine link' condition as a requirement for all European nationality legislations would open up a Pandora's box of brands of ethnic nationalism. It is playing with fire to inflate the flat criterion of nationality, which until now has sufficed, rightly so, as a ticket to Union citizenship. ${ }^{27}$

\footnotetext{
${ }^{25}$ Case C-221/17 ( Tjebbes and others. The Dutch government announced in its coalition agreement (10 October 2017) a comprehensive modernization of its nationality law in March 2017, but nothing has come out of this promise yet.

${ }^{26}$ See the excellent paper by Sergio Carrera (above footnote 16.) Cf H.U. Jessurun d'Oliveira, Nudging in Europees nationaliteitsrecht. Olivier Vonk c.s. (eds), Grootboek. Opstellen aangeboden aan Prof. mr. Gerard-René de Groot (2016) p.215-228.

${ }^{27}$ Is the fact that, five centuries ago, your (my) Sephardic ancestors have been banished from the Iberian peninsula a link genuine enough to warrant the acquisition of the Portuguese or Spanish nationality by descent? See H.U. Jessurun d'Oliveira, "Iberian nationality Legislation and Sephardic Jews. 'With Due regard to Union Law'?" in: Sergio Carrera and Gerard-René de Groot (eds.), European Citizenship at the Crossroads (2016), p.251-265.
} 
The acceptance by the Union and its member states of persons as Union citizens, although they lost their nationality of a member state under municipal legislation, and, contrariwise, the refusal to accept persons as Union citizens in spite of their holding the nationality of a member state, may presumably have repercussions on the nationality legislation of the states involved. Member states may want to adapt their rules to the reactions of the Union and the other member states in terms of Union citizenship. That is their discretion, their reserved domain, according to international law, just as it is for other states and the Union to take a position as to the effects in their legal orders. This position must rest on considerations concerning the exigencies of international conventions, customary international law, and the principles generally recognised with regard to nationality, some of these conventions being part and parcel of the Union legal order including its Charter and the ECHR. Nudging is allowed, dictating not.

\section{The fundamental status}

'Union citizenship is destined to be the fundamental status of nationals of the Member States (...)'. Fifteen years ago, the ECJ issued this futuristic clarion blast for the first time, in Grzelczyk ${ }^{28}$ It repeated the formula one year later in Baumbast and $R^{29}$, and picked it up again in Rottmann ${ }^{30}$, in slightly different wording: 'destined' was changed into 'intended'. Whether this change was intentional is not clear, although it seems that the Court saw no difference. ('As the Court has several times stated').It may have indicated a shift from its own vision ('destined') to deference to the vision of the lawmakers ('intended'). Be that as it may, one is allowed, and even invited to try and figure out what this 'fundamental status' is about.

In the first place, there is its relationship to the nationality, citizenship, of the member states. As I see it, the status is emancipating itself from ius tractus, as Kochenov calls it, from being fully dependent of the laws on nationality of the member states, to an autonomous status which in turn defines the boundaries of these nationality laws. The tables are being turned and the laws on nationality have to conform with the exigencies of Union law and principles. Inroads are being trodden into the reserved domain. Union citizenship has indeed in this respect become fundamental, the laws of the member states are becoming derivative and dependent.

In the second place: although the bulk of the case-law of the ECJ concerns the extent of freedom of movement, it is clear that there is a shift in attention from mobile citizens to those who stay at home. Many rights attached to Union citizenship can be exercised at home: franchise for the EP, right of petition, right to approach the European Ombudsman. This fact undermines any doctrine on 'the internal case' and 'reverse discrimination'. ${ }^{31}$ The Union citizen cannot be defined in terms of his whereabouts; wherever he is, he can claim a number of rights under the treaties as a Union citizen. Most Union citizens stay at home, do hang their hat there, and enjoy their status as Union citizens, although they encounter negative aspects of the freedom of movement of mobile citizens there as well. The proof of solidarity is in accepting displacement and possibly what is framed as social dumping. By cutting the citizen loose from his economic activities, the Treaties have expanded Union citizenship (in a practical sense) from a mere $2 \%$ of the populations to 100 percent and more, given the fact that there are quite a number of nationals of member states residing in third countries as well, counting as Union citizens, though not living in the territories of the member states. In the third place, there is the swing from market citizen to citizens as political actors. The Union citizen is politicised in that he exerts political power not only in

\footnotetext{
${ }^{28}$ C-184/99, Grzelczyk, 20 september 2001, para.31. In Dutch: 'De hoedanigheid van burgers van de Unie dient immers de primaire hoedanigheid van de onderdanen van de Lidstaten te zijn (...)'.

29 Baumbast and R, C- 413/99,17 September 2002, para. 82.

${ }^{30}$ Rottmann, para. 43. In Dutch: 'moet de primaire hoedanigheid van de onderdanen van de Lidstaten zijn.'

${ }^{31}$ See already H.U. Jessurun d'Oliveira, The Community Case. Is reverse discrimination still permissible under the Single European Act?, in Forty Years On: The Evolution of Post-war Private International Law, Kluwer, 1990 , p. 71-86.
} 
electing his representatives in the European Parliament, but in the respective national parliaments as well. Both bodies are institutions of the Union as controllers and law-makers; they have grown in power. Union citizens have franchise in local government as well. They have a collective right to initiative. They vote in national referenda on Union issues. The so-called democratic deficit is not so much being caused by the institutional arrangements, but by the lack of enthusiasm of the people as political actors. The non-voters have little ground to decry the lack of democracy in the Union; the low turnouts at national elections in many member states are mirrored by the elections for the European Parliament. Democratic deficit may also be defined as the waning trust of the European populations in the workings of their existing democracies and politicians and the problem of which of the manifold regulating and policy making institutions and agencies to address. ${ }^{32}$ We need more active citizens!

There remain a lot of desiderata. New pies in the sky. To name a few: Union citizenship should be extended to long-term residents on the territories of the Union Member states. The content of Union citizenship should be expanded in several ways in various areas, not only to make the concept more coherent, but also to offer the beneficiaries more rights in the Union and all of its member states. This means doing away with the doctrine of the internal case, a long overdue exercise. One cannot uphold the idea of Union citizenship with concomitant rights that can be exercised in part in the home member state, one cannot create an area without internal frontiers, and at the same time maintain internal borders. Petit à petit l'oiseau fait son nid!

\footnotetext{
${ }^{32}$ Cf. Luuk van Middelaar, De nieuwe politiek van Europa (2017) part 4, p $277 \mathrm{ff}$.
} 
